\title{
The Efficiency of Tanzanian Macroeconomic Policies in Adhering to Its International Budget Constraints
}

\author{
Muhidini Zungo Maliwaza Mbwana $(\mathrm{PhD})$ \\ Department of Agricultural Economics, University of Dar es Salaam, \\ P.O. Box 35431, Dar es Salaam, Tanzania
}

\begin{abstract}
This study used yearly time series data for imports and exports from 1976 to 2018. These data were obtained from the International Monetary Fund (IMF) data portal. The present paper analyzes whether Tanzanian total imports and total exports share a long run relationship which means testing if they are cointegrated or not. The implication is that if exports and imports share the long run relationship (cointegrated), then the Tanzanian macroeconomic policies are not violating country's international budget constraints. On the other hand, if the two time series variables are not cointegrated, then Tanzanian macroeconomic policies are in violation of its international budget constraints. The series for both variables were found to be integrated of order one i.e. I(1). Thus, the two variables are not stationary in their levels but were found stationary in their first difference. The residuals saved from the estimated long run) equation (cointegration regression between the two variables were found to be stationary at $5 \%$ significance level which suggests the existence of long run relationship (cointegration) between total imports and total exports in Tanzania. Moreover, the error correction model (ECM) results suggested that exports have more impact in correcting disequilibria in imports since about $26.49 \%$ of the disequilibrium in imports are corrected each year. Also, findings show that about $16.43 \%$ of the disequilibrium in exports are corrected each year. On the other hand, a bidirectional causal reference was found between the two variables based on causality results of the specified ECM.
\end{abstract}

Keywords: International budget constraints, Cointegration, Error correction model, Macroeconomic policies, Exports, Imports

DOI: $10.7176 / \mathrm{JEP} / 11-24-10$

Publication date: December $31^{\text {st }} 2020$

\section{Introduction}

International trade is an inevitable practice which a country must involves as long as it operates in an open economy. This is due to the fact that there is no any country which can satisfy by itself for everything from its economy. Therefore, each country including Tanzania concentrates on the production of goods and services of which it has comparative advantage. In this regard, each country involves in international trade so as to gain benefits from the trade in order to ensure a sustainable economic growth. Data from World Bank show that in 2017, the contribution of foreign trade for Tanzania was about $32.2 \%$ of the total Tanzanian gross domestic product (GDP). However, over many decades, in many cases developing countries including Tanzania, have been net importers of the foreign trade implying that they have been experiencing a deficit balance of goods and services for a long period of time. One of the contributing factors to this trend, is the fact that majority of developing countries export low value produce mainly agricultural produce which have relatively low value comparing to the imported goods.

In the course of promoting the economy, many countries have been undertaking several interventions or policies by the government in order to influence major macroeconomic variables such as to ones related to international trade performances. Indeed, the most critical intervention marked is the trade liberalization which was implemented in many countries especially developing countries in early 1980s. The aim of introducing this intervention was to reduce substantially the direct engagement of government in major economic activities. This policy requires the government to engage in the supervisory task so as to promote competition in the markets. Tanzania is one among the countries which accepted this policy in its economic sectors including Agricultural markets. The policy impacted the major macroeconomic indicators including but not limited to imports and exports in the context of international trade. Specifically, the reforms that Tanzania has undertaken since 1985, and at a more accelerated pace in the past few years, have resulted in a trade policy framework that has been significantly liberalized and that is mainly based on tariffs (UNCTAD/WTO 2006). Therefore, export restrictions and foreign exchange controls have been reduced overtime. The paper aim to report a trend of international trade and policy efficiency towards international trade

\section{Problem statement and justification}

Various economic reports ${ }^{1}$ by the Bank of Tanzania (BOT), show that Tanzania has been experiencing trade deficit for its current account in general and goods and services accounts in particular. For instance, the visible balance

\footnotetext{
${ }^{1}$ The economic reports by BOT referred in this paper include monthly economic reviews, quarterly economic bulletins and annual reports
} 
of trade for Tanzania in 2017 was TZS -8456 Billion (BOT 2019). Likewise, it is well known that the imports and exports behaviour of any country does not change spontaneously rather it takes a long time so as to change. This implies that time factor plays an important role in influencing country's trade volume in international trade. Therefore, if in the long run the prevailing trade deficit in each financial year is not sustainable, it creates great pressure on the country's foreign reserves. For Tanzania especially as the country's economy experiences industrial growth the improvement of foreign currency is increasing important in importing capital goods to support industrialization policy. Thus, an understanding of time series behaviour of trade volume in international trade is very crucial in providing insightful for trade policy analysis and effectiveness of macroeconomic policies in ensuring adherence to international budget constraints.

There is a number of previous studies which analyzed the performance of key macroeconomic indicators using econometric techniques. According to Uddin (2009), in order to investigate collective effect of many policies on international trade, one can look for the long-run equilibrium relationship between exports and imports. For example, Tang (2006) studied cointegrating relationship between exports and imports of 27 selected Organization of the Islamic Conference (OIC) member countries. However, to the best of the authors' knowledge, no attempt has been done to carry out an empirical analysis to investigate the long-run relationship between imports and exports of goods and services in Tanzanian using Cointegration and Causality techniques. The use of these techniques helps to assess whether Tanzania adheres to its international budget constraints or not. Therefore, this paper amongst others is an attempt aiming at contributing toward filling this knowledge gap. The study will contribute key information and knowledge on long-run relationship between exports and imports of goods and services that is crucial in making decisions related to macroeconomic policies in general and international trade policies in particular.

\subsection{Review of the relevant literature}

\subsection{Previous studies on the long run relationship between Imports and Exports}

The long-run relationship between exports and imports has been receiving great attention by many researchers in the world. There are several studies which analyzed the long run relationship between exports and imports. A summary of the previous studies which researched the long-run relationship between exports and imports is presented in the appendix of this study. Specifically, the summary of the reviewed literatures shows the author(s) of each work, the title of the study, nature of the data used (time series data and the interval used such as monthly, quarterly or yearly data), year of the study, analytical method(s) used, key findings and the implication of the findings.

\subsection{International trade trend for Tanzania}

3.2.1 Trend for exports and Imports of goods and services in Tanzania

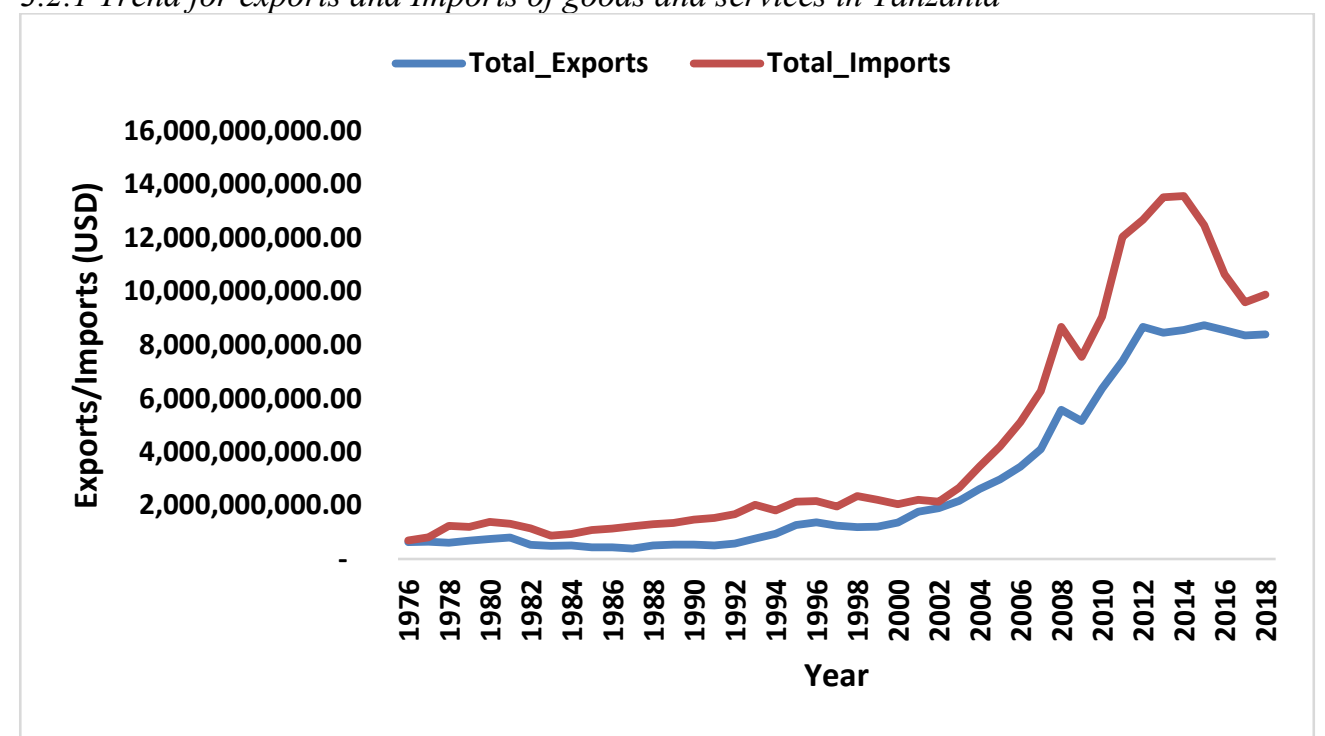

Figure 2. The trend of Tanzanian exports and Imports from 1976 to 2018

Source: International Monetary Fund (IMF)

The trend of both exports and imports of goods and services from 1976 to 2018 shows an upward trend with some fluctuations. Essentially, the trend shows that in almost all years, imports has been above the exports which shows a trade deficit to the country. 


\subsubsection{Trade deficit for Tanzania}

In addition, the trade deficit tends to get wider especially in recent years. This might be attributed by the increasing population in Tanzania due to urbanization and hence high demand for importation.

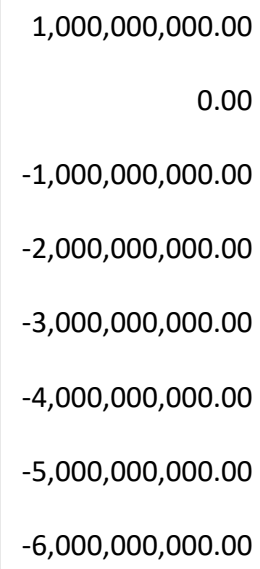

Figure 3. Trend of trade deficit for Tanzania from 1976 to 2018

Source. Authors calculation based on data by IMF

Figure 2 above shows the trend of the trade deficit between 1976 to 2018. Moreover, the trend line (in red colour) shows the general increase in the gap between exports and imports. The slope for the trend line is a bit steeper which suggests further increasing of the trade deficit figure in the near future.

\section{Methodology \\ 4.1 Theoretical framework}

Imports and exports of goods and services are two important macroeconomic indicators which are used to determine the gain or loss of a country in the international trade. Thus, the country can face deficit, balance or surplus balance of goods and services depending on the value of these indicators. Husted (1992) proposed a simple model which can be used to explain and analyze imports and exports of a country. According to Husted (1992), we have consumers who live in a small open economy without government intervention. Thus, the main objective of the consumers is to maximize their utility function subject to budget constraint. In addition, they borrow and lend in international markets based on predetermined interest rate worldwide so as to attain the maximum utility desired. Furthermore, Husted (1992) postulates that consumers are endowed with both outputs and profits from firms. Thus, the revenues they obtain is either consumed or saved.

Indeed, the above explanation can be referred to a national level in such a way that the amount a country borrows from international markets equals the present value of future surpluses (Husted, 1992). He further argues that the amount a country lends to international markets equals present value of its future deficits. This situation explained by Husted (1992) is referred as country's inter-temporal budget constraints. Thus, the above arguments can mathematically be expressed as follows:

$\mathrm{C}_{0}=\mathrm{Y}_{0}+\beta_{0}-\mathrm{I}_{0}-\left(1+\mathrm{r}_{\mathrm{t}}\right) \beta_{\mathrm{t}-1}$

Where:

$\mathrm{Y}_{0}$ Is output

$\mathrm{C}_{0}$ Is consumption

$\beta_{0}$ Is a foreign borrowing

$\mathrm{I}_{0}$ Is investment

$r_{t}$ Is the one-period world interest rate

$(1+r) \beta_{t-1}$ Is historically given initial debt or the accumulated past debt at current rate of interest

Based on the budget constraint equation, Husted (1992) developed a test hypothesis model as:

EXPORTS $_{\mathrm{t}}=\beta_{1}+\sigma$ IMPORTS $_{\mathrm{t}}+\mu_{\mathrm{t}}$

According to Arize (2002), equation (2) can also be tested as:

IMPORTS $_{\mathrm{t}}=\beta_{2}+$ EEXPORTS $_{\mathrm{t}}+\varepsilon_{\mathrm{t}}$

Where:

$\beta_{1}$ and $\beta_{2}$ are the intercepts

$\sigma$ and $\theta$ are the parameters estimated

$\mu_{\mathrm{t}}$ and $\varepsilon_{\mathrm{t}}$ are the normal error terms 


\subsection{Conceptual framework}

The long-run linkages between total imports and total exports depend much on a number of factors especially government interventions or policies. For instance, the trade liberalization policy creates distortions and hence affect the transmission of shocks between total imports and total exports in one way or another. Thus, any attempt to study the long-run relationship between imports and exports must take into consideration the interventions or policies by the government as the main factor in the determination of the nature of long-run relationship of the two variables. The imposition of tariff on international trade (imports or exports) by the government is likely to affect the trade volume of a country in the international trade. However, the decisions of the country's policies in international trade with the rest of the world are also influenced by the international agreements such as those made in World Trade Organization (WTO), regional communities such East African Community (EAC), Southern African development community (SADC). Similarly, the intervention by the government in foreign exchange trade such as foreign exchange rationing and control of exchange rates will directly affect the volume of both imports and exports of a country.

Indeed, the present paper employed econometric techniques namely Cointegration and error correction model. Therefore, only the values of total imports and exports were used in the analysis as per the requirements of the techniques used. The interactions of these variables are summarized as per conceptual framework below.

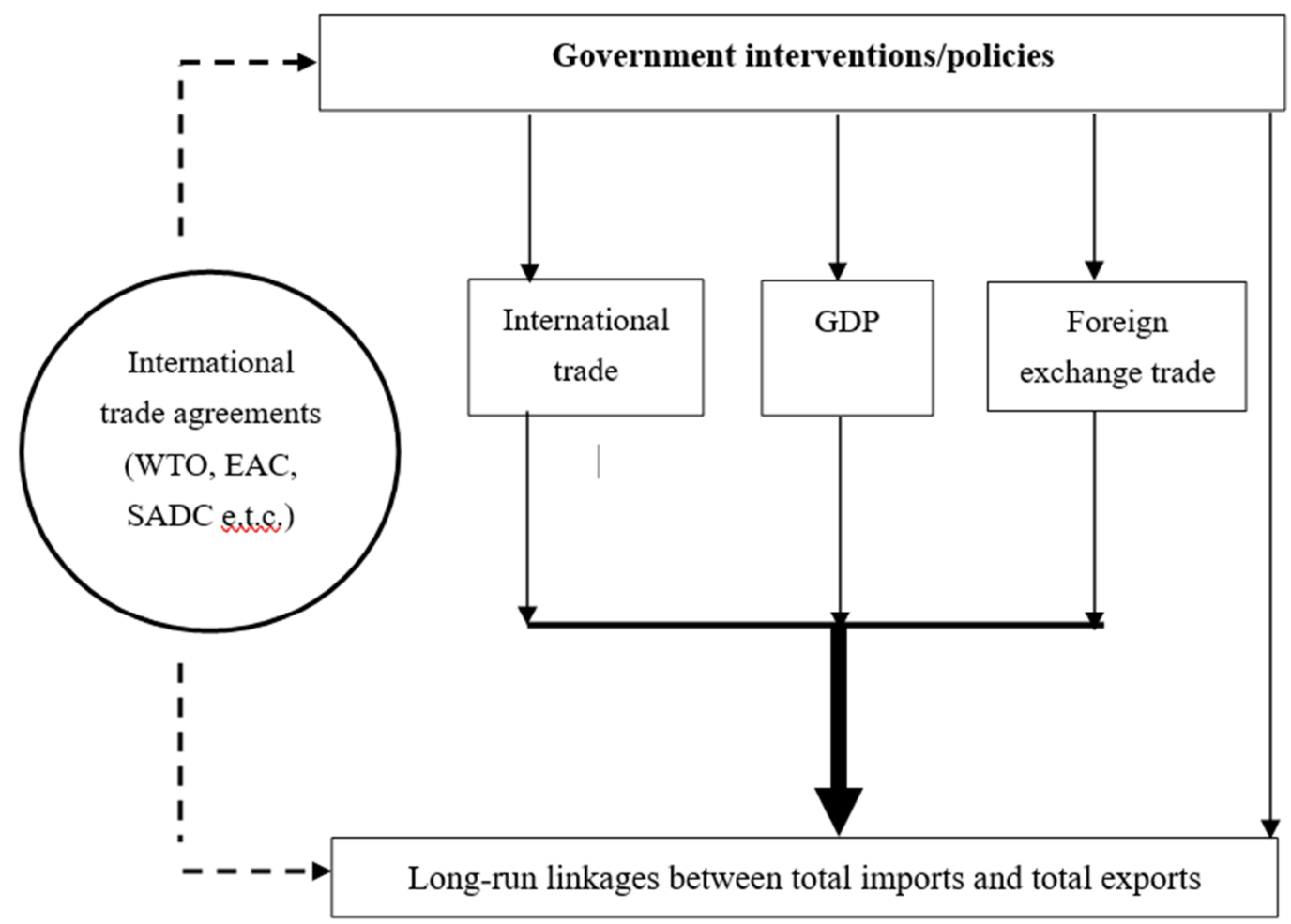

Figure 3. Conceptual framework (Authors)

Note: Dotted and non-dotted lines imply indirect (external) and direct (internal) influence respectively.

\subsection{Analytical framework}

This study employed the two steps procedure of testing cointegration and expressing error correction mechanism based on Engle and Granger (1987). Thus, before any further analyses, the study tests the existence of unit root (random walk) in the series ${ }^{1}$ of imports and exports using Augmented Dickey-Fuller (ADF) test (Dickey and Fuller, 1981). In the unit root tests, the Augmented Dickey- Fuller (ADF) test consists of estimating the following general regression:

$$
\Delta \mathrm{Y}_{\mathrm{t}}=\beta+\delta \mathrm{Y}_{\mathrm{t}-1}+\sum_{\mathrm{m}=1}^{\mathrm{M}} \alpha_{\mathrm{m}} \Delta \mathrm{Y}_{\mathrm{t}-\mathrm{m}}+\varepsilon_{\mathrm{t}}
$$

Where:

$\Delta$ is the difference operator; $\varepsilon_{t}$ is a white noise error term $\Delta \mathrm{Y}_{\mathrm{t}-1}=\left(\mathrm{Y}_{\mathrm{t}-1}-\mathrm{Y}_{\mathrm{t}-2}\right), \Delta \mathrm{Y}_{\mathrm{t}-2}=\left(\mathrm{Y}_{\mathrm{t}-2}-\mathrm{Y}_{\mathrm{t}-2}\right)$ etc. For the case of this study, "Y" can be the imports or exports.

\footnotetext{
${ }^{1}$ The series for imports and exports were expressed in natural logarithm to simplify interpretation and calculations.
} 
The null hypothesis is that $\delta=0$; that is there is a unit root and the alternative hypothesis is that $\delta<0$; this means the time series is stationary.

In the first step of testing cointegration between imports and exports, equation (5) below was estimated using ordinary least square technique (OLS). In the second step, residuals $\hat{\mu}_{t}$ were estimated based on equation (6) below and then the unit root test was conducted on these residuals.

EXPORTS $_{t}^{\text {TZ }}=\alpha+\pi$ IMPORTS $_{t}^{\text {TZ }}+\mu_{t}$

$\hat{\mu}_{t}=$ EXPORTS $_{t}^{\text {TZ }}-\widehat{\alpha}-\widehat{\pi}$ IMPORTS $_{t}^{T Z}$

Where:

$\alpha$ is the constant (intercept)

$\widehat{\pi}$ is the parameter to be estimated

$\hat{\mu}_{t}$ is the estimated error term

The error-correction mechanisms between imports and exports were expressed using models in equation (7) and (8). (ECM) was estimated so as to measure short run and long-run causality and speed of adjustment for the disequilibria in imports and exports. The ECM adopted in this paper takes the following specifications:

$\triangle$ IMPORTS $_{\mathrm{t}}^{\mathrm{TZ}}=\varnothing+\delta \mathrm{ECT}_{\mathrm{t}-1}+\Psi_{i} \Delta$ EXPORTS $_{\mathrm{t}}^{\mathrm{TZ}}+\gamma_{\mathrm{t}}$

$\Delta$ EXPORTS $_{\mathrm{t}}^{\mathrm{TZ}}=\emptyset^{\prime}+\delta^{\prime} \mathrm{ECT}_{\mathrm{t}-1}^{\prime}+\Psi_{\mathrm{k}}^{\prime} \Delta$ IMPORTS $_{\mathrm{t}}^{\mathrm{TZ}}+\gamma_{\mathrm{t}}^{\prime}$

Where:

Imports and exports are expressed in natural logarithm

$\Delta$ is the difference operator; thus, $\Delta$ IMPORTS $_{t}^{\mathrm{TZ}}=\mathrm{IMPORTS}_{\mathrm{t}}^{\mathrm{TZ}}-\mathrm{IMPORTS}_{\mathrm{t}-1}^{\mathrm{TZ}}$

$\emptyset$ and $\emptyset^{\prime}$ are intercepts (constants)

$\Psi$ and $\Psi^{\prime}$ are the short run speed of adjustment

$\gamma_{\mathrm{t}}$ and $\gamma_{\mathrm{t}}^{\prime}$ are the normal error term

$\delta$ and $\delta^{\prime}$ are represent long run speed of adjustment

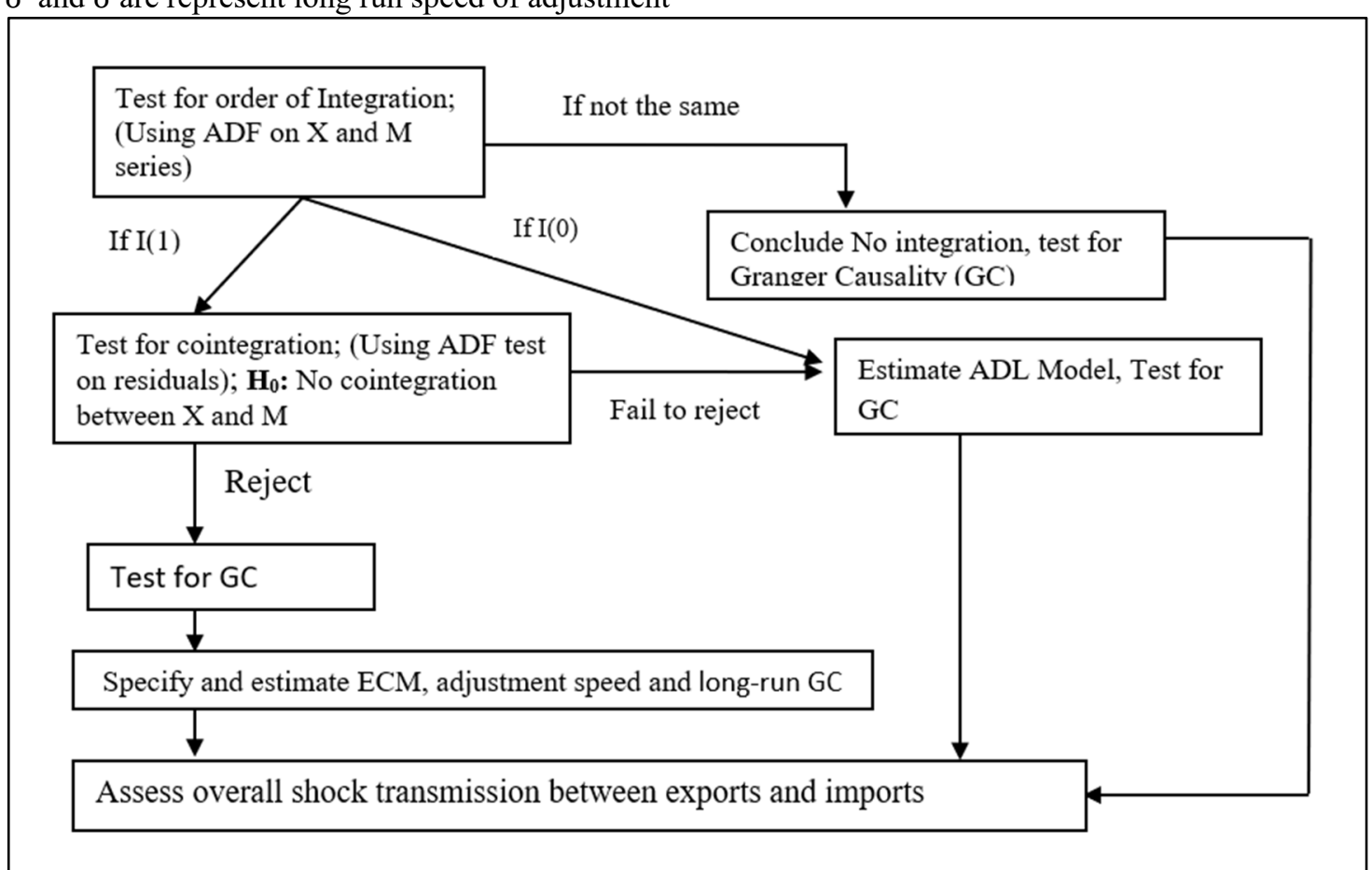

Source. Modified from Rapsomanikis et al. (2003)

Figure 4. Analytical framework for the analysis of long-run relationship using cointegration and causality techniques

\subsection{Data sources and types}

The present paper used secondary data obtained from International Monetary Fund (IMF) data portal ${ }^{1}$. Specifically, the annual time series data on imports and exports of goods and services from 1976 to 2018 were used for this study.

\footnotetext{
${ }^{1}$ The data on imports and exports of goods and services from IMF data portal was preferred to the one which can be sourced from the Bank of Tanzania (BOT) website since the observations for the latter case are relative fewer than the former. This follows the fact that cointegration and causality studies are appropriate especially when high frequency data are used in order to ensure validity of the findings of the study.
} 


\section{Results and discussion}

5.1 Unit root test

Table 1. ADF test results for imports (M) and exports (X)

\begin{tabular}{|l|c|c|c|c|}
\hline $\begin{array}{c}\text { Variable in natural } \\
\log \end{array}$ & Number of lags & Level & Number of lags & First difference \\
\hline EXPORTS & 3 & $-0.082(0.9512)$ & 1 & $-3.410^{* *}(0.0106)$ \\
\hline IMPORTS & 2 & $-0.159(0.9432)$ & 1 & $-3.883^{*}(0.0022)$ \\
\hline
\end{tabular}

Figures in parentheses are $\mathrm{P}$ values whereby $*$ and $* *$ denote statistical significance at $1 \%$ and $5 \%$ respectively.

The first stage was to test for the presence of unit root using Augmented Dickey Fuller (ADF) test as per the analytical framework adapted in this paper. Indeed, the lags for the ADF test for natural log of total imports and exports time series were selected based on the Akaike Information Criterion (AIC). The null hypothesis was not rejected when the unit root test was done to the levels for both variables implying that the series are not stationary (Table 1). However, the null hypothesis was rejected after the ADF test was done on their first difference for the two variables (Table 1). This means the series for both variables are integrated of order one i.e. I(1).

\subsection{Cointegration test for imports and exports}

The cointegration regression was estimated based on equation (5) above. Thereafter, the residuals were estimated from the estimated cointegrating regression then ADF test was conducted on these residuals. It was found that the residuals are stationary at 5\% significance level. This implies that the country's exports and imports have the long run relationship. Moreover, the economic implication of this finding tells us that Tanzanian macroeconomic policies are efficient in ensuring the country (Tanzania) does not violate its international budget constraints.

Therefore, the existence of long-run relationship between imports and exports suggests at least a unidirectional causal relationship between the two Macroeconomic variables. As a result, the Error Correction Model (ECM) was estimated in order to explore the long-run causality and speed of adjustment of the disequilibria in both imports and exports.

\subsection{Error correction model results}

Table 2 Error correction models results based on Engle \& Granger (1987)

\begin{tabular}{|c|c|c|c|c|}
\hline $\begin{array}{c}\text { Dependent } \\
\text { variable }\end{array}$ & $\begin{array}{c}\text { Independent } \\
\text { variable }\end{array}$ & $\begin{array}{c}\text { Error correction term } \\
\text { (ECT)/Long-run adjustment } \\
\text { speed }\end{array}$ & Short-run & $\begin{array}{c}\text { Causal } \\
\text { reference }\end{array}$ \\
\hline$\Delta$ IMPORTS $_{\mathrm{t}}^{\mathrm{TZ}}$ & $\Delta \mathrm{EXPORTS}_{\mathrm{t}}^{\mathrm{TZ}}$ & $-0.2649187^{*}(-3.03)$ & $0.5137956^{*}(3.74)$ & $\begin{array}{l}\text { Bidirectional } \\
\text { causality } \\
\text { observed }\end{array}$ \\
\hline$\Delta \mathrm{EXPORTS}_{\mathrm{t}}^{\mathrm{TZ}}$ & $\Delta \mathrm{IMPORTS}_{\mathrm{t}}^{\mathrm{TZ}}$ & $-0.1642755^{* *}(-2.10)$ & $0.4992612^{*}(3.60)$ \\
\hline
\end{tabular}

The figures in parentheses are "t" values. The $\left(^{*}\right)$ and $(* *)$ represent significant at $1 \%$ and $5 \%$ respectively.

In terms of long run speed of adjustment, imports tend to adjust relatively faster than export does. Specifically, the estimated $\mathrm{ECM}^{1}$ has the error correction term (ECT) of -0.2649 or $-26.49 \%$. In this case, it means each year about $26.49 \%$ of the disequilibrium in imports is corrected to restore its long-run steady state (equilibrium state between imports and exports). On the other hand, the estimated ECM ${ }^{2}$ has an ECT of -0.1643 or $-16.43 \%$. This implies that about $16.43 \%$ of the disequilibrium in exports is corrected each year. The values for ECTs in both ECMs are negative and significant. This suggests that the ECT acts as a significant force which causes the integrated variables (imports and exports) to return to their long run relation when they deviate from it in both cases. The probability of the F-statistic in all cases are significant at $1 \%$ showing the robustness of the model specification. On the other hand, the short run speed of adjustment is $49.93 \%$ and $51.48 \%$ when exports and imports are dependent variables respectively. On the other hand, the causality test based on the ECM showed a bidirectional causal reference between exports and imports. This means the two variables granger cause each other. Therefore, this causal reference implies that the two variables can be used to forecast each other.

According to Irandoust \& Ericsson (2004), cointegrating relationship between exports and imports explains that a country is not in violation of her international budget constraints and that trade imbalances are short term phenomenon and macroeconomic policies have been effective to bring exports and imports into equilibrium in the long-run. This is due to the fact that lack of cointegration indicates the problem in the macroeconomic policies of a country particularly in the international trade. Thus, the observed long-run relationship between Tanzanian imports and exports of goods and services is of paramount importance since it reflects the sustainability of foreign trade situation of a country. Hence, it can be concluded that the government of Tanzania has been performing better in stabilizing the trade balance i.e. exports and imports. Moreover, it has been making sure that the overall macroeconomic policies are effective in directing imports and exports into a long-run steady state equilibrium

\footnotetext{
${ }^{1}$ Keeping change in imports as the dependent variable and the change in exports as the independent variable.

${ }^{2}$ Keeping change in exports as the dependent variable and the change in imports as the independent variable.
} 
relationship. On the other hand, it can be concluded that export has more impact on imports based on the observed findings for the values of error-correction terms.

\section{Conclusion}

This paper reveals that total imports and total exports of goods and services in Tanzania from 1976 to 2018 are non-stationary time series and, indeed, they are integrated of order one i.e. I(1). The two variables share the long run relationship and, thus, any imbalance observed is only for the short run since in the long run the disequilibria are corrected through the error correction term. The implication of these findings is the existence of the effectiveness in the implementation of the macroeconomic policies in Tanzania which means the country operates within its international budget constraint. Moreover, the causality results from ECMs suggest the existence of bidirectional causal relationship between exports and imports which means the two variables can be used to forecast each other.

The findings of the paper are very useful in encouraging the underway efforts by the government of Tanzania to improve the economy of the country including foreign trade especially by targeting improvement in production of traditional crops such as sisal, cotton, tobacco and the like. These are the crops which constitute a substantial share of the exports' revenue for the country. On the other hand, the expected increase of foreign earnings from exports is important for strengthening industrialization process which in turn is also good for reducing the gap between exports and imports. Thus, the effectiveness of the macroeconomic policies is very crucial in ensuring the sustainability of the trade deficit through ensuring the cointegration between exports and imports. On the other hand, the effectiveness of the macroeconomic policies is important in reducing the trade deficit for the country.

\section{Recommendation}

Notwithstanding the results of this paper, authors recommend that, the government of Tanzania should continue with its efforts aiming at promoting industrialization in the country as part of the import substitution policy in order to meet some of the key demands of the country using domestic production. This will be a great and crucial initiative towards reducing the trade deficit which has been facing the country more often while enhancing country's foreign currency reserve.

Specifically, authors advise the policymakers to undertake a thorough consideration regarding the recovery of old industries in the country and formation of new industries which will exploit the production capacity of the country especially in the agricultural crops where it has comparative advantage. This will not only reduce the trade deficit, but also will improve the gross national product (GNP) of the country since the net factor income from abroad (NFIA) will be improved as one of the components of GNP calculation which reflects the gain or loss from the foreign trade.

\section{References}

Arize, A. (2002). Imports and Exports in 50 Countries: Tests for Cointegration and Structural Breaks. International Review of Economics and Finance, 11(1), 101-15.

Bank of Tanzania. (2019). Tanzania in figures.

Dickey, D. A. \& Fuller, W. A. (1981). "Likelihood Ratio Statistics for Autoregressive Time Series with a Unit Root", Econometrica, Vol. 49, pp.1057-72.

Engle, R.F. \& Granger C.W.J. (1987). "Cointegration and Error Correction: Representation, Estimation and Testing”, Econometrica, Vol. 55, pp. 251-276.

Husted, S. (1992). The emerging U.S current Account Deficit in the 1980s: A cointegration Analysis Review of Economics and Statistics. 74(1): 159-166.

Irandoust, M., \& Ericsson, J. (2004). Are imports and exports cointegrated? an international comparison. Metroeconomica, 55 (1), 49-64.

Laryea, S. A. \& Sumaila, U. R. (2001). Determinants of inflation in Tanzania. Working paper number 12. Development studies and human rights. Chr. Michelsen Institute, Norway.

Rapsomanikis, G., Hallam, D. \& Conforti, P. (2003). Market Integration and Price Transmission in Selected Food and Cash Crop Markets in Developing Countries: Review and Applications. Commodity Market Review No. 04. Food and Agriculture Organization, Rome. 120pp.

Tang, T. C. (2006). Are imports and exports in the OIC member countries cointegrated? a reexamination. IIUM Journal of Economics and Management. 14 (1), 1-31.

Uddin, J. (2009). Time Series Behavior of Imports and Exports of Bangladesh: Evidence from Cointegration Analysis and Error Correction Model. International Journal of Economics and Finance. 1(2): 156-162.

UNCTAD/WTO. (2006). Country report (Tanzania). Vol. 3. Pp. 62

USAID (2005). Tanzania Economic performance Assessment. 
Appendix. Summary of previous studies on similar subject matter i.e. long-run relationship between exports and imports

\begin{tabular}{|c|c|c|c|c|c|c|}
\hline Author(s) & Title & $\begin{array}{l}\text { Nature and } \\
\text { interval of } \\
\text { the data used }\end{array}$ & Year & $\begin{array}{l}\text { Analytical } \\
\text { method }\end{array}$ & Key findings & $\begin{array}{l}\text { Implication of } \\
\text { the findings }\end{array}$ \\
\hline \multirow[b]{2}{*}{$\begin{array}{l}\text { Arshia } \\
\text { Amiri and } \\
\text { Ulf-G } \\
\text { Gerdtham }\end{array}$} & \multirow{2}{*}{$\begin{array}{l}\text { Relationship } \\
\text { between } \\
\text { exports, } \\
\text { imports, and } \\
\text { economic } \\
\text { growth in } \\
\text { France: } \\
\text { evidence from } \\
\text { cointegration } \\
\text { analysis and } \\
\text { Granger } \\
\text { causality with } \\
\text { using } \\
\text { geostatistical } \\
\text { models }\end{array}$} & \multirow[b]{2}{*}{$\begin{array}{l}\text { Time series } \\
\text { data/Annual } \\
\text { data on real } \\
\text { GDP, exports } \\
\text { and Imports. }\end{array}$} & \multirow[b]{2}{*}{2011} & \multirow[b]{2}{*}{$\begin{array}{l}\text { Cointegration } \\
\text { analysis and } \\
\text { Granger } \\
\text { causality } \\
\text { using } \\
\text { geostatistical } \\
\text { models }\end{array}$} & $\begin{array}{l}\text { trade stimulates } \\
\text { economic } \\
\text { growth of France } \\
\text { in long run. }\end{array}$ & \multirow[b]{2}{*}{$\begin{array}{l}\text { International trade } \\
\text { policies in France } \\
\text { are effective in } \\
\text { ensuring } \\
\text { Economic growth. }\end{array}$} \\
\hline & & & & & \begin{tabular}{l}
\multicolumn{2}{l}{ unidirectional } \\
effect between \\
exports growth \\
and imports \\
growth in long \\
run.
\end{tabular} & \\
\hline \multirow{2}{*}{$\begin{array}{l}\text { Tahir } \\
\text { Mukhtar } \\
\text { and } \\
\text { Sarwat } \\
\text { Rasheed }\end{array}$} & \multirow{2}{*}{$\begin{array}{l}\text { Testing long- } \\
\text { run } \\
\text { relationship } \\
\text { between } \\
\text { exports and } \\
\text { imports: } \\
\text { Evidence from } \\
\text { Pakistan }\end{array}$} & \multirow{2}{*}{$\begin{array}{l}\text { Time-series } \\
\text { data/Quarterly } \\
\text { data for } \\
\text { exports, } \\
\text { imports and } \\
\text { nominal } \\
\text { exchange rate. }\end{array}$} & \multirow[b]{2}{*}{2010} & \multirow{2}{*}{$\begin{array}{l}\text { Cointegration } \\
\text { analysis and } \\
\text { Granger } \\
\text { causality } \\
\text { using Vector } \\
\text { error } \\
\text { correction } \\
\text { model }\end{array}$} & $\begin{array}{l}\text { Existence of } \\
\text { long-run } \\
\text { relationship } \\
\text { between exports } \\
\text { and imports. }\end{array}$ & \multirow{2}{*}{$\begin{array}{l}\text { Overall } \\
\text { Macroeconomic } \\
\text { policies are } \\
\text { effective in } \\
\text { bringing exports } \\
\text { and imports into } \\
\text { the long-run } \\
\text { steady state } \\
\text { equilibrium } \\
\text { (Trade balances } \\
\text { are sustainable in } \\
\text { the long-run for } \\
\text { Pakistan) }\end{array}$} \\
\hline & & & & & $\begin{array}{l}\text { Bidirectional } \\
\text { causality } \\
\text { between exports } \\
\text { and imports. }\end{array}$ & \\
\hline $\begin{array}{l}\text { Afaf } \\
\text { Abdull J. } \\
\text { Saaed and } \\
\text { Majeed } \\
\text { Ali } \\
\text { Hussain }\end{array}$ & $\begin{array}{l}\text { Impact of } \\
\text { Exports and } \\
\text { Imports on } \\
\text { Economic } \\
\text { Growth: } \\
\text { Evidence from } \\
\text { Tunisia }\end{array}$ & $\begin{array}{l}\text { Time series } \\
\text { data/Annual } \\
\text { data on } \\
\text { Export, } \\
\text { Import and } \\
\text { economic } \\
\text { growth }\end{array}$ & 2015 & $\begin{array}{l}\text { Cointegration } \\
\text { and Granger } \\
\text { causality } \\
\text { analysis }\end{array}$ & $\begin{array}{l}\text { there is } \\
\text { unidirectional } \\
\text { causality } \\
\text { between exports } \\
\text { and imports and } \\
\text { between exports } \\
\text { and economic } \\
\text { growth. }\end{array}$ & $\begin{array}{l}\text { Economic growth } \\
\text { in Tunisia was } \\
\text { propelled by a } \\
\text { growth -led } \\
\text { import strategy as } \\
\text { well as export led } \\
\text { import. }\end{array}$ \\
\hline $\begin{array}{l}\text { Sharafat } \\
\text { Ali }\end{array}$ & \begin{tabular}{lr}
\multicolumn{2}{l}{ Cointegration } \\
Analysis of \\
Exports and \\
Imports: The \\
Case \\
Pakistan \\
Economy
\end{tabular} & $\begin{array}{l}\text { Time series } \\
\text { data/The time } \\
\text { interval for } \\
\text { the data was } \\
\text { not specified. }\end{array}$ & 2013 & $\begin{array}{l}\text { Cointegration } \\
\text { and Granger } \\
\text { causality } \\
\text { analysis }\end{array}$ & $\begin{array}{l}\text { Existence of } \\
\text { long-run } \\
\text { relationship } \\
\text { between exports } \\
\text { and imports. }\end{array}$ & $\begin{array}{l}\text { Macroeconomic } \\
\text { policies in } \\
\text { Pakistan are } \\
\text { effective in } \\
\text { stabilizing the } \\
\text { international trade } \\
\text { balance. }\end{array}$ \\
\hline
\end{tabular}




\begin{tabular}{|c|c|c|c|c|c|c|}
\hline \\
\hline AUTHORS & TITLE & $\begin{array}{c}\text { NATURE } \\
\text { AND } \\
\text { INTERVAL } \\
\text { OF THE } \\
\text { DATA } \\
\text { USED }\end{array}$ & YEAR & $\begin{array}{l}\text { ANALYTICAL } \\
\text { METHOD }\end{array}$ & $\begin{array}{c}\text { KEY } \\
\text { FINDINGS }\end{array}$ & $\begin{array}{c}\text { IMPLICATION } \\
\text { OF THE } \\
\text { FINDINGS }\end{array}$ \\
\hline $\begin{array}{l}\text { Dierk } \\
\text { Herzer and } \\
\text { Felicitas } \\
\text { nowak- } \\
\text { lehmann D. }\end{array}$ & $\begin{array}{l}\text { Are exports } \\
\text { and imports of } \\
\text { Chile } \\
\text { cointegrated? }\end{array}$ & $\begin{array}{l}\text { Time series } \\
\text { data/Annual } \\
\text { data on for } \\
\text { exports and } \\
\text { imports. }\end{array}$ & 2005 & $\begin{array}{l}\text { Cointegration } \\
\text { analysis }\end{array}$ & $\begin{array}{l}\text { Existence of } \\
\text { long-run } \\
\text { relationship } \\
\text { between } \\
\text { exports and } \\
\text { imports. }\end{array}$ & $\begin{array}{l}\text { Chile's } \\
\text { macroeconomic } \\
\text { policies have } \\
\text { been effective in } \\
\text { the long-run and } \\
\text { suggests that } \\
\text { Chile is not in } \\
\text { violation of its } \\
\text { international } \\
\text { budget } \\
\text { constraint. }\end{array}$ \\
\hline $\begin{array}{l}\text { Olumuyiwa } \\
\text { Olamade } \\
\text { and } \\
\text { Oluwasola } \\
\text { Oni }\end{array}$ & $\begin{array}{l}\text { Exports and } \\
\text { Imports } \\
\text { Cointegration: } \\
\text { Further } \\
\text { Evidence } \\
\text { from the } \\
\text { ECOWAS }\end{array}$ & $\begin{array}{l}\text { Time series } \\
\text { data/Annual } \\
\text { data on } \\
\text { exports and } \\
\text { imports. }\end{array}$ & 2016 & $\begin{array}{l}\text { Bound testing } \\
\text { approach to } \\
\text { Cointegration, } \\
\text { Autoregressive } \\
\text { distributed lag } \\
\text { model (ARDL) }\end{array}$ & $\begin{array}{l}\text { Existence of } \\
\text { long-run } \\
\text { relationship } \\
\text { between } \\
\text { exports and } \\
\text { imports for } 8 \\
\text { countries out } \\
\text { of } \\
\text { countries } 13 \\
\text { under the } \\
\text { study. }\end{array}$ & $\begin{array}{l}\text { Majority of the } \\
\text { countries under } \\
\text { the study are not } \\
\text { violating their } \\
\text { international } \\
\text { budget } \\
\text { constraint. }\end{array}$ \\
\hline $\begin{array}{l}\text { Amina } \\
\text { Ahec Šonje, } \\
\text { Boris } \\
\text { Podobnik } \\
\text { and } \\
\text { Maruška } \\
\text { Vizek }\end{array}$ & $\begin{array}{l}\text { Long-run } \\
\text { relationship } \\
\text { between } \\
\text { exports and } \\
\text { imports in } \\
\text { transition } \\
\text { European } \\
\text { countries }\end{array}$ & $\begin{array}{l}\text { Time series } \\
\text { data/ } \\
\text { Quarterly } \\
\text { data on } \\
\text { exports and } \\
\text { imports. }\end{array}$ & 2010 & $\begin{array}{l}\text { Cointegration } \\
\text { analysis }\end{array}$ & $\begin{array}{l}\text { Existence of } \\
\text { long run } \\
\text { relationship } \\
\text { between } \\
\text { exports and } \\
\text { imports for } \\
10 \text { countries } \\
\text { out of } 16 \text { EU } \\
\text { countries } \\
\text { under the } \\
\text { study. }\end{array}$ & $\begin{array}{l}\text { The } \\
\text { Macroeconomic } \\
\text { policies of the } \\
\text { countries found } \\
\text { with a stable } \\
\text { long run relation } \\
\text { are effective for } \\
\text { adhering to } \\
\text { international } \\
\text { budget } \\
\text { constraints. }\end{array}$ \\
\hline $\begin{array}{l}\text { Mohammad } \\
\text { Zillur } \\
\text { Rahman }\end{array}$ & $\begin{array}{l}\text { Existence of } \\
\text { Export-Import } \\
\text { Cointegration: } \\
\text { A Study on } \\
\text { Indonesia and } \\
\text { Malaysia }\end{array}$ & $\begin{array}{l}\text { Time series } \\
\text { data/ The } \\
\text { interval of } \\
\text { the data was } \\
\text { not } \\
\text { specified in } \\
\text { a paper. }\end{array}$ & 2011 & $\begin{array}{l}\text { Cointegration and } \\
\text { Granger causality } \\
\text { analysis }\end{array}$ & $\begin{array}{l}\text { There is } \\
\text { cointegration } \\
\text { between } \\
\text { exports and } \\
\text { imports for } \\
\text { Malaysia } \\
\text { and no } \\
\text { cointegration } \\
\text { observed for } \\
\text { Indonesia. }\end{array}$ & $\begin{array}{l}\text { The Malaysian } \\
\text { economy is } \\
\text { performing well } \\
\text { regarding the } \\
\text { effectiveness of } \\
\text { its } \\
\text { Macroeconomic } \\
\text { policies. }\end{array}$ \\
\hline
\end{tabular}




\begin{tabular}{|c|c|c|c|c|c|c|}
\hline Authors & Title & $\begin{array}{l}\text { Nature and } \\
\text { interval of the } \\
\text { data used }\end{array}$ & Year & $\begin{array}{c}\text { Analytical } \\
\text { method }\end{array}$ & Key findings & $\begin{array}{l}\text { Implication of } \\
\text { the findings }\end{array}$ \\
\hline $\begin{array}{l}\text { Jamal } \\
\text { Husein }\end{array}$ & $\begin{array}{l}\text { Are exports } \\
\text { and imports } \\
\text { cointegrated } \\
\text { ? Evidence } \\
\text { from nine } \\
\text { MENA } \\
\text { countries }\end{array}$ & $\begin{array}{l}\text { Time series data/ } \\
\text { The interval of } \\
\text { the data was not } \\
\text { specified in a } \\
\text { paper. }\end{array}$ & 2014 & $\begin{array}{l}\text { Bound testing } \\
\text { approach to } \\
\text { Cointegration }\end{array}$ & $\begin{array}{l}\text { No } \\
\text { cointegration } \\
\text { between } \\
\text { exports and } \\
\text { imports for five } \\
\text { countries } \\
\text { namely } \\
\text { Algeria, Sudan, } \\
\text { Syria, Egypt, } \\
\text { and Morocco } \\
\text { while } \\
\text { cointegration } \\
\text { between } \\
\text { exports and } \\
\text { imports was } \\
\text { observed for } \\
\text { four countries } \\
\text { namely Jordan, } \\
\text { Iran, Israel and } \\
\text { Tunisia. }\end{array}$ & $\begin{array}{l}\text { The } \\
\text { Macroeconomic } \\
\text { policies of the } \\
\text { countries found } \\
\text { with a stable } \\
\text { long run } \\
\text { relation are } \\
\text { effective for } \\
\text { adhering to } \\
\text { international } \\
\text { budget } \\
\text { constraints. }\end{array}$ \\
\hline $\begin{array}{l}\text { Musibau } \\
\text { Adetunji } \\
\text { Babatund } \\
\text { e }\end{array}$ & $\begin{array}{l}\text { Are Exports } \\
\text { and Imports } \\
\text { Cointegrated } \\
? \quad \text { Evidence } \\
\text { from Nigeria }\end{array}$ & $\begin{array}{l}\text { Time series } \\
\text { data/Annual } \\
\text { data on } \\
\text { Aggregate } \\
\text { imports (RTM) } \\
\text { aggregate } \\
\text { exports (RTX), } \\
\text { oil imports } \\
\text { (ROM), oil } \\
\text { exports (ROX), } \\
\text { nonoil exports } \\
\text { (RNX) and non- } \\
\text { oil exports } \\
(\mathrm{RNM})\end{array}$ & 2014 & $\begin{array}{l}\text { Bound testing } \\
\text { and the } \\
\text { Hansen } \\
\text { parameter } \\
\text { instability test } \\
\text { cointegration } \\
\text { techniques }\end{array}$ & $\begin{array}{l}\text { Nigerian } \\
\text { exports and } \\
\text { imports at the } \\
\text { aggregate and } \\
\text { disaggregated } \\
\text { level are } \\
\text { cointegrated }\end{array}$ & $\begin{array}{l}\text { Nigeria's } \\
\text { macroeconomic } \\
\text { policies have } \\
\text { been effective } \\
\text { in the long run } \\
\text { and suggested } \\
\text { that Nigeria is } \\
\text { not in violation } \\
\text { of its } \\
\text { international } \\
\text { budget } \\
\text { constraint. }\end{array}$ \\
\hline $\begin{array}{l}\text { Abdulla } \\
\text { S. Al- } \\
\text { Khulaifi }\end{array}$ & $\begin{array}{l}\text { Exports and } \\
\text { imports in } \\
\text { Qatar: } \\
\text { evidence } \\
\text { from } \\
\text { cointegration } \\
\text { and error } \\
\text { correction } \\
\text { model }\end{array}$ & $\begin{array}{l}\text { Time series } \\
\text { data/Annual } \\
\text { data on exports } \\
\text { and imports. }\end{array}$ & 2013 & $\begin{array}{l}\text { Cointegration } \\
\text { and Granger } \\
\text { causality using } \\
\text { error } \\
\text { correction } \\
\text { model }\end{array}$ & $\begin{array}{l}\text { Exports and } \\
\text { imports were } \\
\text { found to be } \\
\text { cointegrated } \\
\text { while imports } \\
\text { were found to } \\
\text { Granger cause } \\
\text { exports in the } \\
\text { long-run. }\end{array}$ & $\begin{array}{l}\text { Qatar is not in } \\
\text { violation of its } \\
\text { international } \\
\text { budget } \\
\text { constraints, and } \\
\text { macroeconomic } \\
\text { policies have } \\
\text { been effective } \\
\text { in bringing } \\
\text { exports and } \\
\text { imports into a } \\
\text { long-run } \\
\text { equilibrium. }\end{array}$ \\
\hline $\begin{array}{l}\text { Yangru } \\
\text { Wu and } \\
\text { Junxi } \\
\text { Zhang }\end{array}$ & $\begin{array}{l}\text { Are the U.S. } \\
\text { Exports to } \\
\text { and Imports } \\
\text { from Japan } \\
\text { Cointegrated } \\
?\end{array}$ & $\begin{array}{l}\text { Time series data/ } \\
\text { The quarterly } \\
\text { flows of U.S. } \\
\text { imports from } \\
\text { and exports to } \\
\text { Japan. }\end{array}$ & 1998 & $\begin{array}{l}\text { Cointegration } \\
\text { analysis/Struct } \\
\text { ural break } \\
\text { analysis. }\end{array}$ & $\begin{array}{l}\text { Imports and } \\
\text { exports are } \\
\text { cointegrated. }\end{array}$ & $\begin{array}{l}\text { The U.S.-Japan } \\
\text { trade deficit } \\
\text { may not be "too } \\
\text { large i.e. the } \\
\text { trade deficit is } \\
\text { sustainable. }\end{array}$ \\
\hline
\end{tabular}

